\title{
Amphibians of Gniezno
}

\author{
Waclaw ADAMIAK \\ "Milenium" College of Humanities and Management of Gniezno, \\ ul. Pstrowskiego 3a, 62-200 Gniezno, Poland; e-mail: waclaw.adamiak@autograf pl
}

\begin{abstract}
From 2005 to 2007 the water bodies in the area of Gniezno have been controlled to establish amphibian species composition and their number. Thirty four of water bodies were under observation. In 23 among them (67.6\%) the following species of amphibians were present: common frog Rana temporaria, moor frog Rana arvalis, "water frogs" Rana esculenta complex, common spadefoot, fire-bellied toad Bombina bombina, common toad Bufo bufo; green toad Bufo viridis; and smooth newt Triturus vulgaris. "Water frogs" and common frog formed the largest populations. Great crested newt Triturus cristatus, natterjack toad Bufo calamita, and tree frog Hyla arborea were not observed.
\end{abstract}

Key words: amphibians, urban habitat, Wielkopolska

\section{INTRODUCTION}

The lowland species of amphibians, typical of the whole area of Wielkopolska are as follows: great crested newt, Triturus cristatus (Laurenti, 1768), smooth newt, Trituris vulgaris (Linnaeus, 1758), fire-bellied toad, Bombina bombina (Linnaeus, 1761), common spadefoot, Pelobates fuscus (Laurenti, 1768), common toad, Bufo bufo (Linnaeus, 1758), green toad, Bufo viridis Laurenti, 1768, natterjack toad, Bufo calamita (Laurenti, 1768), tree frog, Hyla arborea (Linnaeus, 1758), moor frog, Rana arvalis Nilsson, 1842, common frog, Rana temporaria Linnaeus, 1758, edible frog, Rana kl. esculenta Linnaeus, 1758, pool frog, Rana lessonae Camerano, 1882, marsh frog, Rana ridibunda Pallas, 1771 (Rybacki 2002, Rybacki \& Berger 2003).

Habitats in the area of Wielkopolska have been undergoing rapid transformations, forced by the growing industry and agriculture. Dynamic processes of changes of fauna and flora take place there (Banaszak 2003), also affecting the habitat of amphibians, which due to their heightened susceptibility to environmental changes are particularly at risk (Rybacki 2002, Rybacki \& Berger 2003).

A particularly adverse influence of the anthropogenic effects on the number of amphibians is present in cities, which makes the living conditions in those areas acutely unfavorable for amphibians (Siwak \& Chętnicki 2002). In urban areas, apart from global conditions endangering the life of amphibians, the main causes of their decline are considered to be the lack of small reservoirs with clear water in which reproduction takes place, and the increasing traffic (Krzyściak-Kosińska 2000). 
The species composition and number of species of the population of amphibians are rapidly changing in the dynamically changing urban environment. The difficulties in defining the scale of this phenomenon arise mainly from the insufficient knowledge of the count of amphibians in the cities and of the habitats in which they live (Sura \& Rybacki 1998). For this reason compiling a long-term and systematically repeated inventory in urban areas is needed. The results of such research allow for an estimation of the present population of amphibians in the given area as well as an analysis of the changes which the populations of particular species undergo (Mazgajska 1998) and are necessary for decision making of the state and local authorities, which concerns planning and realization of industrial goals and nature preservation (Schimscheiner \& Kal 2004).

The aim of the work was to: 1) conduct an inventory of amphibians in the bodies of water in Gniezno area, and 2) estimate the number of particular species of amphibians in the examined bodies of water.

\section{STUDY AREA}

Gniezno is the largest town of the Gniezno Lake District, located in the north-eastern part of the Greater Poland Lowlands. It is an agricultural area, with few woods (Kondracki 2002). Gniezno has a population of about 70 thousand people, covering an area of 40.89 square kilometers. The town is abundant in green areas. Within its area lie lakes: Winiary (19.37 ha), Świętokrzyskie (16.19 ha) and Jelonek (15.33 ha), as well as many ponds, ditches, pits left after minerals have been mined. Woodlands cover 542 ha of the towns" surface. In total, the green areas, that is woods, and woodlands, arable land, meadows, orchards, and fruit and vegetable gardens constitute $44 \%$ of the town's surface.

The very center of the town, with its characteristic, congested housing is relatively small and covers 60.75 ha, which amounts to $1.46 \%$ of the town's area. The new housing developments: Winiary (67.5 ha), Grunwaldzkie (36 ha) and Ustronie (47 ha) cover together with the town center 211.25 ha, i.e. $5.11 \%$ of the whole area of the town. The buildings in the rest of the town are scattered.

There is a railroad running through the middle of the town of the Poznań-Inowroclaw line. On its northern side 23 bodies of water have been examined: lake Koszyk (no. 1), pond in Osiedle Kazimierza Wielkiego (no. 2), garden pool in Powstańców Wielkopolskich street (no. 3), lakes Winiary (no. 4) and Świętokrzyskie (no. 6). There also exist a couple of ponds - in Rycerska street (no. 5), next to the cathedral in Seminaryjna street (no. 8), in Os. Tysiąclecia (no. 9), Mogileńska street (no. 10), Roosevelta street (no. 11), Wieśniacza street (no. 12), Poznańska street (no. 13) and shallow backwater in the meadows in Os. Kustodia (no. 7). In the center of the town there is the lake Jelonek (no. 14). In Sobieskiego street there is a small pond (no. 15), and the next pools of water of the same kind exist in the town park (Park Miejski - no. 16 and 17), Piastowski Park (no. 18), in Wierzbiczany street (no. 20), Wschodnia street (no. 21), Fredry (no. 22), and in Konikowo street (no, 19) a garden pond. In the meadows in Baczyńskiego street (no. 23) there are pits filled with water, abandoned after the peat had been extracted. 
In the southern part of town the following bodies of water have been examined: water hole in Os. Dalki (no. 24), industrial storage reservoirs of a closed sugar factory in Kostrzewskiego street (no. 25), field ponds Kawiary (no. 26) and Osiniec (no. 27), local pond in Ślusarska street (no. 28), pits in Wiejska street (no. 29), storage reservoir in Wolności street (no. 30), ponds in Pulkowa street (no. 31) and Glogowa street (no. 32), lake Zacisze (no. 33) as well as a group of small pits close together in Nowaszki street (no. 34).

The detailed characteristic of the 34 controlled bodies of water can be found in Appendix 1 . They amount to about $75 \%$ of all bodies of water within the city limits. Among them, 10 bodies of water (29.4\%) are natural; five of them are lakes within the city limits, and the other five are pits of different sizes and depth, usually surrounded by meadows, created a few dozen years ago after peat, gravel, or sand in those places had been extracted.

The remaining bodies of water $(70.6 \%)$ bear visible traces of human interference. As many as 20 among them $(58.7 \%)$ are typical ponds. Five of them $(14.7 \%)$ have the bed hardened with concrete slabs and their banks strengthened with stakes and fascine. The next two (5.8\%) are garden ponds, the banks and beds of which are laid with foil. The storage reservoir in Kostrzewskiego street (no. 25) has a typically industrial character and its water was used by the sugar factory which has been closed since a few years. The storage reservoir in Wolności street (no. 30), is also of great utilitarian value since it gathers rain water in the region. The bodies of water with strengthened banks and beds constitute $23.5 \%$ of all reservoirs controlled during taking inventory of amphibians in Gniezno area. The accessibility of a given body of water, as well as its importance for reproduction and growth of amphibians depends on its position within the city limits. For that reason each of the controlled bodies of water has been, depending on its surroundings, qualified as one of the classes of urban space (Appendix 1).

The most numerous bodies of water (38.22\%) lie next to meadows, grazing grounds and undeveloped areas with characteristics of green wastelands. $20.58 \%$ of the bodies of water lie in parks and other urban green areas. Among the low, scattered buildings there are $29.40 \%$ of the reservoirs, but only one pond (2.94\%) lying in Osiedle Kazimierza Wielkiego (no. 2) is surrounded by tall residential houses. Three bodies of water $(8.82 \%)$ are garden ponds in fruit and vegetable gardens.

\section{Methods}

The preliminary list of bodies of water which were planned to be included in observation, was prepared on the basis of the town maps. During the process of compiling the inventory, the list was broadened to include other bodies of water which had been found to exist in the area.

Field observations connected with the inventory of amphibians in Gniezno area had begun in 2005 (Adamiak 2006) and were continued during 2006 and 2007. The research was conducted during the breeding seasons of amphibians, i.e. from March to 
June, when all adult specimen of every species gather in the bodies of water. The inventory was complied while walking along the reservoirs' banks, when the number of live and dead specimen of adult amphibians was recorded. The duration of observation time depended on the size of a given body of water and lasted from 15 minutes to 2-3 hours. During the whole research period each reservoir was visited at least 6 times. Pond has been classified as a breeding site if presence of adult amphibians in breeding season, characteristic of the species, was confirmed.

The species of amphibians were determined according to the classification key of amphibians (Glowaciński \& Rafinski 2003). The correct classification of species of "water frogs" is difficult due to their close morphological similarity and matching habitats (Juszczyk 1987), as well as occurrence of specimen with shared traits. Berger's research proved that the population of "water frogs" consists of not only pool frog Rana lessonae and marsh frog Rana ridibunda but also their crossbreeds (Uzzell \& Berger 1975, Berger \& Czarniewska 2002). For that reason this group of amphibians was named Rana esculenta complex (Blab \& Vogel 1999, Buszko-Briggs \& Okolów 2002).

The number of amphibians in a given body of water was determined according to the highest number of specimen observed. In order to determine the size of population in respective bodies of water, three quantitative classes of amphibians have been assumed (Strijbosch 1979; after Mazgajska 1998), assuming that class 1 designates up to 20 specimens, class 2 from 21 to 100 specimens, and class 3 over 100 specimens.

\section{RESULTS}

The bodies of water in which the presence of breeding amphibians has been detected are evenly located across the town of Gniezno. During the observation amphibians have been found in 23 water bodies (67.6\%) out of 34 investigated (Appendix 1). While the observation was being conducted, the following species of amphibians in Gniezno area have been found: Rana temporaria, Rana arvalis, Pelobates fuscus, Bombina bombina, Bufo bufo, Bufo viridis, Triturus vulgaris and groups of water frogs (Rana esculenta complex). On average $( \pm \mathrm{sd})$, every single controlled body of water contained $1.50 \pm 1.31$ species, and the reservoirs chosen as place of reproduction contained $2.21 \pm 1.31$ species of amphibians.

The number of breeding amphibians in a given water body varied from several to several hundred specimens. As a rule their populations were not large, up to 100 specimens (Table 1). At the time, the most numerous populations were formed by "water frogs" and the common frog. Water frogs (Rana esculenta complex) were found to occur most frequently in controlled water bodies $(58.8 \%)$.

Mating specimens of the great crested newt, natterjack toad and the tree frog were not found in the controlled water bodies.

The most preferred breeding site of amphibians was the Wierzbiczany pond (no. 20 ), surrounded by meadows and located in an area with low buildings. Five species 
Table 1. Frequency of breeding amphibians' occurrence and their estimated abundance in studied bodies of water in Gniezno.

\begin{tabular}{|c|c|c|c|c|c|}
\hline \multirow[t]{2}{*}{ No } & \multirow[t]{2}{*}{ Species } & \multirow{2}{*}{$\begin{array}{l}\text { Number of water bodies } \\
(\%) \text { used for breeding }\end{array}$} & \multicolumn{3}{|c|}{$\begin{array}{l}\text { Nuniber of water lodies in } \\
\text { particular class of abundance }\end{array}$} \\
\hline & & & $1-20$ & $21-100$ & $>100$ \\
\hline 1 & Rana temporaria & $10(29.4 \%)$ & 4 & 4 & 2 \\
\hline 2 & Rana arvalis & $5(14.7 \%)$ & 2 & 3 & \\
\hline 3 & Rana esculenta complex & $20(58.8 \%)$ & 9 & 5 & 6 \\
\hline 4 & Pelobates fuscus & $2(5.9 \%)$ & 2 & & \\
\hline 5 & Bombina bombina & $3(8.8 \%)$ & 3 & & \\
\hline 6 & Bufo bufo & $6(17.6 \%)$ & 5 & 1 & \\
\hline 7 & Bufo viridis & $3(8.8 \%)$ & 3 & & \\
\hline 8 & Triturus vulgaris & $2(5.9 \%)$ & 2 & & \\
\hline
\end{tabular}

have been found there, i.e. $62.5 \%$ of all taxa of amphibians present in Gniezno area. The lake Zacisze (no. 33), with shallow water and overgrown banks, 4 species (50.0\%) were present, i.e. a half of all species of amphibians in Gniezno area. Three species of amphibians (37.5\%) had been mating in each: Winiary lake (no. 4), in the pits in Os. Kustodia (no. 7), in Dalki pond (no. 24) and in the industrial storage reservoir in Kostrzewskiego street (no. 25) and in the storage reservoir in Wolności street (no. 30).

\section{Discussion}

As a result of detailed research 13 species of amphibians have been found to exist in the Wielkopolska area. The most extensively researched area in Wielkopolska is, as regards the condition of amphibian fauna, General Dezydery Chlapowski Landscape Park near Kościan. Researches of amphibians have been conducted here continuously since the 1960s. Particularily intensive and detailed research of amphibians in this area was conducted in 1995-1997 (Rybacki \& Berger 1997, Berger \& Rybacki 1998, Karg et al. 2003). The Park territory is a fragment of typical, agricultural landscape of Greater Poland.

The closest major city in vicinity of Gniezno is Poznań. In 1993 the inventory of amphibians was produced by Pawlowski (1993). According to his findings, 12 species of amphibians live in Poznań area. If we regard "water frogs" as one taxonomic group (Rana esculenta complex) then there are 11 taxa of amphibians in Greater Poland, 10 in Poznań area, and 9 in Warsaw (Mazgajska 1998).

During the observations conducted in Gniezno area 7 species of amphibians have been recognized to exist, as well as the represented in large numbers group of "water frogs" (Rana esculenta complex), which constitutes $72.7 \%$ of species of amphibians living in Greater Poland area, and $80.0 \%$ in Poznań. 
According to Pawlowski (1993) the smooth newt is not fastidious about its choice of reservoirs for breeding and in Poznan can be found abundantly in the very center of the city. Similar observations are applicable to Warsaw (Mazgajska 1998) and Bialystok (Siwak \& Chętnicki 2002). In Gniezno area this species has been found only in two ponds $(5.9 \%)$ located in the outskirts of town, in clear, shallow water and on gentle, grassy banks. The aforementioned authors agree that the great crested newt is a very rare species in Poznan and Warsaw. It has not been found in Gniezno area.

The European fire-bellied toad is rare in both Poznan and Warsaw. In Gniezno its presence has been confirmed at three locations (8.8\%). Pawlowski (1993) described the common spadefoot as quite common in Poznań, living mainly in areas of character close to natural habitat, as less numerous in vicinity of housing developments. In Gniezno the presence of the common spadefoot was only found at two locations, which constitute $5.9 \%$ of all bodies of water. A similar result $-6.6 \%$ was obtained by Mazgajska (1998) in her research in the area of Warsaw.

According to Juszczyk (1987) the green toad is among all Polish amphibians the species the most strongly connected with built-up areas. The thesis is confirmed by Pawlowski (1993), who observed this species of toad on the mating grounds in ponds which were located within the limits of Poznan's congested housing. The results obtained by Mazgajska (1998) for Warsaw and Siwak \& Chętnicki (2002) for Bialystok confirm the view that the green toad is a common animal in city centers. In Gniezno its presence was confirmed in three ponds $(8.8 \%)$, but in ponds surrounded by green areas.

Pawlowski (1993) affirmed that the common toad is the most common and the most numerous amphibian in Poznan area, although it is not present in the city center. In Warsaw area (Mazgajska 1998) this species shows no dominance and in the city center it was observed only in large green areas. Also in Gniezno for its mating grounds it choses bodies of water of natural character, such as lakes Jelonek and Zacisze, as well as badly developed ponds, surrounded by meadows on the outskirts of town.

The common frog and the moor frog in big cities with congested housing are common only in the outskirts (Pawlowski 1993, Mazgajska 1998). In Gniezno they have been found to be evenly located within the whole town. It is probably the result of Gniezno 's scattered buildings and of the fact that housing developments are separated by large stretches of green areas with many reservoirs. The presence of common frogs was ascertained in ten $(29.4 \%)$, and moor frogs only in five $(14.7 \%)$ bodies of water.

The "water frogs" (Rana esculenta complex) in Gniezno appeared in 20 (58.8\%) bodies of water. As in Poznan (Pawlowski 1993) the "water frogs" are common here and are the most numerous population among all mating amphibians. They inhabit the banks of lakes Winiary, Jelonek, Świętokrzyskie as well as the ponds in the urbanized part of town. This phenomenon proves the thesis that the specimen of this group of amphibians, in particular Rana esculenta, which is the natural crossbreed of the pool frog and marsh frog, display a strong tendency towards claiming new, ecologically diverse habitats (Berger 1969, 2000). 
The existence of large green areas and numerous bodies of water of diverse character and size, provides living and mating conditions for the amphibians in the Gniezno area. One should concur with Soltysiak's opinion (2004) that such places, despite the existent buildings, determine the existence of amphibians in cities. The choice of reservoir by the amphibian is determined by its location relative to urbanized areas, as well as the qualities of the given body of water and its immediate surroundings (Nowakowski et al. 2008). The field researches permit the conclusion that for the place of laying their spawn amphibians require reservoirs with clear, well-oxygenized water, with little organic and mineral matter (Poleszczuk et al. 2002). Rybacki \& Berger (2003) show that the successful development of amphibians at larval stages is also influenced by e.g. the degree of overgrowth of rushes, shade provided by the littoral trees, the presence of fish and domesticated ducks in the given body of water, the water pollution, etc. Without researching these factors it is impossible to explain the reasons for the amphibian present choices of particular bodies of water as their breeding sites in the city area.

\section{REFERENCES}

ADAMIAK W. 2006. Występowanie plazów na terenie Gniezna - wstępne wyniki badań. In: ZaMACHOWSKI W. (ed.). Biologia plazów i gadów - ochrona herpetofauny. VIII Ogólnopolska Konferencja Herpetologiczna. 27-28.09.2006. Kraków, pp. 3-5. Wydawnictwo Naukowe Akademii Pedagogicznej. Kraków, 209 pp.

Banaszak J. (ed.) 2003. Stepowienie Wielkopolski pól wieku później. Wydawnictwo Akademii Bydgoskiej im. Kazimierza Wielkiego. Bydgoszcz, 266 pp.

BERgER L. 1969. Systematics of forms within Rana esculenta complex. Przegląd Zoologiczny 13: 219-238. [in Polish with English summary]

Berger L. 2000. Plazy i gady Polski - Klucz do oznaczania. Wydawnictwo Naukowe PWN. Warszawa - Poznań, 146 pp.

BeRgER L. \& RYBACKi M. 1998. Composition and ecology of water frog populations in agricultural landscape in Wielkopolska. Biological Bulletin of Poznań. Zoology 35: 103-111.

Berger L. \& Czarniewsia E. 2002. Characteristics of western Palearctic water frogs. Przeglad Zoologiczny 46: 189-200. [in Polish with English summary]

BŁ.AB J. \& Voget H. 1999. Plazy i gady Europy Srodkowej. MULTICO Oficyna Wydawnicza. Warszawa. $160 \mathrm{pp}$.

Buszko-Briggs M. \& Okozów G. 2002. Plazy i gady Polski. MULTICO Oficyna Wydawnicza. Warszawa. $119 \mathrm{pp}$.

GıowACiŃski Z. \& RAFÍ́sKi J. (eds). 2003. Atlas of the amphibians and reptiles of Poland. Status - Distribution - Conservation. Biblioteka Monitoringu Środowiska. Warszawa - Kraków. 156 pp. [In Polish with English summary]

Juszczyk W. 1987. Plazy i gady krajowe. Vol. 2. Wydawnictwo Naukowe PWN, Warszawa. 384 pp.

Karg J. Łęcki R.. Szaddak L.. Kujawa K.. Kujawa A. \& Bernacki Z. 2003. Przegląd badań ekologicznych prowadzonych na terenie Parku Krajobrazowego im. gen. D. Chlapowskiego. Biuletyn Parków Krajobrazowych Wielkopolski 9: 30-50.

KonDRACKI J. 2002. Geografia regionalna Polski. Wydawnictwo Naukowe PWN. Warszawa. 450 pp. 
KRZYŚCIAK-Kosińska R. 2000. What threatens amphibians at dawn of the new millennium. Wiadomości Ekologiczne 46: 115-126. [in Polish with English summary]

MAzGAJSKa J. 1998. The studies on batrachofauna in Warsaw in 1992-1994. In: BARCZAK T. \& INDYkiEWICZ P. (eds). Fauna miast - Urban fauna, pp. 227-236. Akademia Techniczno Rolnicza. Bydgoszcz, 263 pp. [In Polish with English summary]

Nowakowski J. J., Górski A. \& Lewandowski K. 2008. Środowiskowe uwarunkowania występowania płazów w drobnych zbiornikach Olsztyna. In: ZAMACHOwsKi W. (ed.), Biologia płazów i gadów - ochrona herpetofauny. IX Ogólnopolska Konferencja Herpetologiczna. 22-23.09.2008, Kraków. pp. 89-94. Wydawnictwo Naukowe Akademii Pedagogicznej. Kraków, 188 pp.

Pawıowski A. 1993. Płazy Poznania. MSc Thesis. Uniwersytet Adama Mickiewicza. Zakład Zoologii Ogólnej. Poznań. 82 pp.

Poleszczuk G.. Piecka-Rapacz M. \& Domagaza J. 2002. Jakie zbiorniki wodne wybierają żaby i ropuchy do rozrodu? Wyniki badań wybranych fizyczno-chemicznych wskaźników jakości wód zbiorników wodnych na terenie Szczecińskiego Parku Krajobrazowego. In: ZAMACHOWSKI W. (ed.), Biologia płazów i gadów - ochrona herpetofauny. VI Ogólnopolska Konferencja Herpetologiczna. 24-26.06.2002. Kraków. pp. 73-74. Wydawnictwo Naukowe Akademii Pedagogicznej. Kraków, 170 pp.

RyBacki M. 2002. Zmiany liczebności populacji plazów w krajobrazie rolniczym Wielkopolski. In: ZAMACHOwski W. (ed.), Biologia płazów i gadów - ochrona herpetofauny. VI Ogólnopolska Konferencja Herpetologiczna, 24-26.06.2002. Kraków, pp. 95-98. Wydawnictwo Naukowe Akademii Pedagogicznej. Kraków, 170 pp.

Rybacki M. \& Berger L. 1997. Plazy Parku Krajobrazowego im. gen. D. Chlapowskiego. Biuletyn Parków Krajobrazowych Wielkopolski 4: 22-40.

Rybacki M. \& Berger L. 2003. Wspólczesna fauna plazów Wielkopolski na tle zaniku ich siedlisk rozrodczych. In: BanaszaK J. (ed.). Stepowienie Wielkopolski - pól wieku później. pp. 143-173. Wydawnictwo Akademii Bydgoskiej im. Kazimierza Wielkiego. Bydgoszcz. $266 \mathrm{pp}$.

Schimscheiner L. \& Kat U. 2004. Plazy Janowic. In: Zamachowski W. (ed.), Biologia plazów i gadów - ochrona herpetofauny. VII Ogólnopolska Konferencja Herpetologiczna. 28-29.09.2004, Kraków, pp. 101-104. Wydawnictwo Naukowe Akademii Pedagogicznej. Kraków. 194 pp.

Siwak P. \& Chętnicki W. 2002. Plazy Białegostoku. In: Zamachowski W. (ed.), Biologia plazów i gadów - ochrona herpetofauny. VI Ogólnopolska Konferencja Herpetologiczna. 24-26.06.2002, Kraków, pp. 101-105. Wydawnictwo Naukowe Akademii Pedagogicznej. Kraków. 170 pp.

SoŁTYSIAK M. 2004. Inwentaryzacja miejsc występowania płazów w Chorzowie - wstępne wyniki badań. In: ZAMACHOWsKi W. (ed.), Biologia plazów i gadów - ochrona herpetofauny. VII Ogólnopolska Konferencja Herpetologiczna, 28-29.09.2004. Kraków, pp. 112-116. Wydawnictwo Naukowe Akademii Pedagogicznej. Kraków. 194 pp.

Sura P. \& Rybacki M. 1998. Losy polskich plazów. Wiedza i Życie 8: 38-39.

Uzzell T. \& Berger L. 1975. Electrophoretic phenotypes of Rana ridibunda, Rana lessonae. and their hybridogenetic associate Rana esculenta. Proceedings of the Academy of Natural Sciences of Philadelphia 127: 13-24. 


\section{STREsZCZENIE}

\section{[Plazy Gniezna]}

W latach 2005-2007 przeprowadzono obserwacje zbiorników wodnych na terenie miasta Gniezna, w celu ustalenia jakie gatunki płazów w nich występują w okresie rozrodczym i jaka jest ich liczebność.

Kontrola objęto 34 zbiorniki wodne. W 23 z nich $(67,6 \%)$ występowaly plazy następujących gatunków: żaba trawna (Rana temporaria), żaba moczarowa (Rana arvalis), żaby zielone (Rana esculenta complex), grzebiuszka ziemna (Pelobates fuscus), kumak nizinny (Bombina bombina), ropucha szara (Bufo bufo), ropucha zielona (Bufo viridis), traszka zwyczajna (Triturus vulgaris). Najliczniejsze populacje tworzyly Rana esculenta complex oraz Rana temporaria. Nie stwierdzono występowania Tritumus cristatus, Bufo calamita oraz Hyla arborea.

Accepted: 16 September 2010 
Appendix 1. Occurrence of amphibians in the particular bodies of water with regard to the features of these bodies, such as: surface area, periodicity, character of the bottom and banks, composition of water vegetation. Periodicity: + - permanent bodies of water - - seasonal bodies of water emptied by the end of summer. Bottom character: + - concrete, - - non-concrete. Location: a - city center, congested housing developments, $\mathrm{b}-$ low, scattered buildings, $\mathrm{c}-$ parks, urban green areas, $\mathrm{d}$ - fruit and vegetable gardens, e - meadows, wastelands. The full names of the bodies of water, corresponding with the numeration used in the table, can be found in the body of the text.

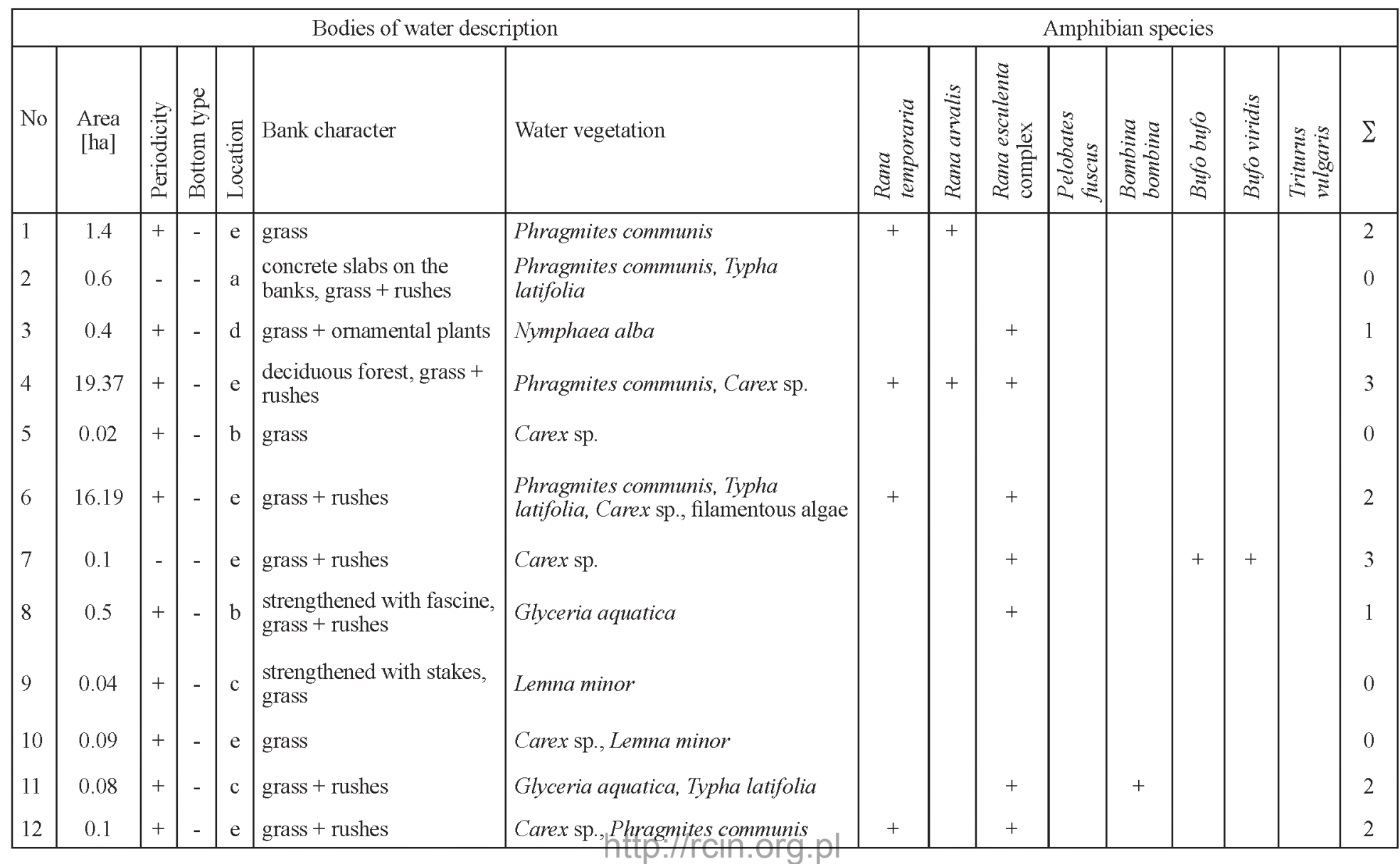




\begin{tabular}{|c|c|c|c|c|c|c|c|c|c|c|c|c|c|c|c|}
\hline 13 & 0.03 & + & + & $\mathrm{c}$ & grass & Nimphea alba & & + & + & & & & & & 2 \\
\hline 14 & 15.33 & + & - & $\mathrm{e}$ & grass + rushes & $\begin{array}{l}\text { Carex sp., Phragmites communis, } \\
\text { Glyceria aquatica Typha angustifolia }\end{array}$ & & & + & & & + & & & 2 \\
\hline 15 & 0.03 & + & - & $\mathrm{c}$ & grass & Lemna minor & & & & & & & & & 0 \\
\hline 16 & 0.4 & + & - & $\mathrm{c}$ & grass & Lemna minor & + & & + & & & & & & 2 \\
\hline 17 & 0.2 & + & - & $\mathrm{c}$ & grass + rushes & $\begin{array}{l}\text { Phragmites communis, Typha } \\
\text { latifolia, filamentous algae }\end{array}$ & & & + & & & & + & & 2 \\
\hline 18 & 0.5 & + & - & $\mathrm{c}$ & grass, osier bed & Lemna minor & + & & & & & & & & 1 \\
\hline 19 & 0.02 & - & + & $\mathrm{d}$ & grass + rushes & $\begin{array}{l}\text { Glyceria aquatica, Typha latifolia, } \\
\text { filamentous algae }\end{array}$ & + & & & + & & & & & 2 \\
\hline 20 & 0.03 & + & - & $\mathrm{e}$ & grass & Carex sp., Glyceria aquatica & & + & + & + & & + & & + & 5 \\
\hline 21 & 0.2 & + & - & $\mathrm{b}$ & grass & Carex sp. & & & & & & & & & 0 \\
\hline 22 & 0.03 & - & - & $\mathrm{b}$ & grass & Glyceria aquatica & & & & & & & & & 0 \\
\hline 23 & 0.02 & + & - & $\mathrm{b}$ & grass + rushes & $\begin{array}{l}\text { Phragmites communis, Typha } \\
\text { angustifolia }\end{array}$ & & & + & & & & & & 1 \\
\hline 24 & 0.1 & + & - & $\mathrm{d}$ & $\begin{array}{l}\text { grass + rushes, sparse } \\
\text { shrub }\end{array}$ & $\begin{array}{l}\text { Phragmites communis, Typha } \\
\text { angustifa, Acorus calamus }\end{array}$ & & & + & & & + & & + & 3 \\
\hline 25 & 7.4 & + & + & $\mathrm{b}$ & laid with concrete slabs & $\begin{array}{l}\text { Phragmites communis, Carex sp., } \\
\text { Typha latifolia, Acorus calamus }\end{array}$ & + & & + & & + & & & & 3 \\
\hline 26 & 0.04 & - & - & $\mathrm{e}$ & grass + rushes & Phragmites communis, Carex sp. & & & + & & & & & & 1 \\
\hline 27 & 0.05 & + & - & $\mathrm{e}$ & grass + rushes & Phragmites communis, Carex sp. & & & + & & & & + & & 2 \\
\hline 28 & 0.03 & + & - & $\mathrm{b}$ & grass & Lemna minor & & & & & & & & & 0 \\
\hline 29 & 0.2 & + & - & $\mathrm{b}$ & grass + rushes & Phragmites communis, Carex sp. & & & & & & & & & 0 \\
\hline 30 & 0.1 & - & + & $\mathrm{b}$ & grass + rushes & $\begin{array}{l}\text { Phragmites communis, Carex sp., } \\
\text { Glyceria aquatica }\end{array}$ & + & + & + & & & & & & 3 \\
\hline 31 & 0.03 & - & + & $\mathrm{b}$ & grass & Lemna minor, filamentous algae & & & & & & & & & 0 \\
\hline 32 & 0.1 & + & - & $\mathrm{e}$ & grass & Carex sp. & & & + & & & + & & & 2 \\
\hline 33 & 2.8 & + & - & $\mathrm{e}$ & grass + rushes, shrub & $\begin{array}{l}\text { Phragmites communis, Carex sp., } \\
\text { Typha angustifolia, filamentous algae }\end{array}$ & + & & + & & + & + & & & 4 \\
\hline 34 & 1.4 & + & - & $\mathrm{e}$ & grass + rushes & $\begin{array}{l}\text { Phragmites communis, Typha } \\
\text { angustifolia, Carex sp. }\end{array}$ & & & & & & & & & 0 \\
\hline
\end{tabular}

